\title{
SOME RECENT PAPERS ON RHEUMATIC DISEASES FROM THE LIBRARY OF THE INTER- NATIONAL LEAGUE AGAINST RHEUMATISM
}

\section{German}

Chronische Polyarthritis nach subtotaler Strumektomie. L. Kirstein and O. Lövgren, Arch.f. Klin. Chir., 1938, Bd. 191, H. 1.

Ist der Bechterew eine Spondyl-Arthritis ? K. Wolff, Deutsche Med. $W s ., 17$ März, 1939, Nr. 11.

Ueber die Behandlung chronischer Formen der Ischias. Ein Beitrag zur Frage fokale Infektion, "Pseudofocus" und Psychotherapie. A. Géronne, Die Med. Welt, 1939, Nr. 12.

Cholesteringehalt im Blut bei physikalischer Hyperthermie. F. Walinski and I. Bleisch, Deutsche Med. Ws., 5 Mai, 1939, Nr. 18.

Ueber das Auftreten der verschiedenen rheumatischen Krankheitsbilder beim schleichend chronischen Wirbelsäulenrheumatismus (Atypischer Morbus Bechterew). O. Köddermann, Münch. Med. Ws., 12 Mai, 1939, Nr. 19.

Lumbago und Ischias-II. J. E. W. Brocher, Zts. f. Klin. Med., 1939, Bd. 136, H. 2.

Behandlung der Ischialgie mit periartikulärer intervertebraler Novocaininjektion. St. Teneff, Der Chirurg, 1939, H. 7.

Allergische Arthritis und Myokarditis. E. Bruun, Virchow's Archiv, 1939, H. 2.

Aussprache über Wert und Gefahren der Goldbehandlung, speziell bei Tuberkulose und chronischen Rheumatismus. O. Schedtler, Med. Klin., Nr. 22.

Beitrag zur Biologie und Pathologie der Gelenke. E. Vaubel, Zts. f. Rheumaf., Juni, 1939, H. 6.

Studien über experimentelle Arthriden und Karditiden. E. Jonsson, Acta Med. Scand., Suppl., Nr. C.

Verkalkung des hinteren Wirbelsäulenlängsbandes bei primär chronischer Polyarthritis. J. E. W. Brocher, Röntgenpraxis, 1939, H. 1.

Ueber den Wirkungsmechanismus organischer Schwefelverbindungen beim Rheumatismus. H. Sieburg, Dts. Med. Ws., 9 Juni, 1939, Nr. 23.

Klinische Auswertung der Anachorese bei fokkaltoxischen rheumatischen Krankheitsbildern. R. Rikl, Dts. Med. Ws., 16 Juni, 1939, Nr. 24.

Gegen Kienböcks " rheumatoide" Gelenkstuberkulose. F. Oehlecker, Dts. Med. Ws., 16 Juni, 1939, Nr. 24. 
Klinische Erfahrungen mit Eupragin bei Lumbago,' Ischias und chronischer Arthritis. F. Schmitt and H. Frigge, Med. Klinik, 23 Juni, 1939, Nr. 25.

Klärung und gerechte Beurteilung einer schweren Spondylarthrose nach Fehlbegutachtung wegen vorausgegangenen Traumas. H. Oppe, Med. Klinik, 23 Juni, 1939, Nr. 25.

Die Bedeutung rheumatischer Krankheiten und ihre Abgrenzung von Unfallverletzungen im Durchgangsarztverfahren. Chr. Vogels, Münch. Med. Ws., 23 Juni, 1939, Nr. 25.

Beitrag zur Frage der tuberkülösen Genese des spezifischen Rheumatismus. G. Franz, Zts.f. Rheumaf., Juli, 1939.

Die Verwendbarkeit einer neuen Seroreaktion zur objektiven Beurteilung von therapeutischen Erfolgen bei Rheumatikern. F. Knüchel, Zts.f. Rheumaf., Juli, 1939.

Anamnestische und klinische Studien an 370 Ischiaskranken unter bes. Berücksichtigung der mit Nervinjektion und Nervdehnung behandelten Fälle. H. Rothenpieler, Münch. Med. Ws., 14 Juli, 1939, Nr. 28.

Ischrheumeu in der Orthopädie. H. Lampadius, Med. Klinik, Nr. 32. Ueber endokrine Ursachen für Gelenkerkrankungen bei der Frau. Tore Rilton, Zts. f. Rheumaf., August, 1939, Bd. ii., H. 8.

Ueber die Röntgenbehandlung cronischer unspezifischer Gelenkleiden. S. N. Bakke, Acta Radiologica, vol. xx.

Operation der Spondylolisthesis durch vordere transabdominelle transplantative Spanversteifung. C. Henschen, Zentralb. $f$. Chir., 1939, Nr. 15.

Gelenktuberkulose unter dem Bilde der Polyarthritis. A. von Domarus, Münch. Med. Ws., S. 1442, 1939.

Kreuzschmerzen und Ischias. R. Kienböck, Münch. Med. Ws., 11 Aug., 1939, Nr. 32.

Die verschiedenen Formen der Gelenkerkrankungen. F. Munk, Zts. Rheumaf., Sept., 1939, Bd. ii.

Beitrag zur Biologie und Pathologie der Gelenke. II. Teil. Die entzündlichen Vorgänge im Gelenk. E. Vaubel. Zts. f. Rheumaf., Sept., 1939, Bd. ii.

Ueber perorale Muskeladenylsäure-therapie spastischer Gefäszerkrankungen in U.S.A. und in Deutschland. H. Köbcke, Deutsche Med. Ws., 10 Nov., 1939, Nr. 45.

Der Rheumatismus und die streptomykotische Symbiose von W. H. Veil. T. Volnard, Zentr. bl. 1. Inn. Med., 25 Nov., 1939.

Die Bedeutung der Senkungsreaktion als unspezifische immunbiologische Reaktion für Fründiagnose. K. v. Neergaard, Münsch. Med. Ws., 1939.

Ueber extraartikuläre Knochenveränderungen bei primärchronischer Polyarthritis. K. Weisz, Forts. a. d. Geb. Röntg. str., Nov., 1939. 


\section{French}

Des affections rhumatismales. M. Ory, Rev. de Thér., Jan., 1939, Nr. 18.

Y a-t-il un antagonisme entre l'ictère et le rhumatisme? Lemaire, Progrès Méd., Fevr., 1939, Nr. 5.

Histoire du rhumatisme extra-articulaire. La notion de fibrosite. M. P. Weil, Rev. du Rhum., Mars, 1939, Nr. 3.

Le rhumatisme fibreux, ses diverses formes. M. P. Weil, Rev. du Rhum., Mars, 1939, Nr. 3.

Le pied rond rhumatismal. L. Michotte, Rev. du Rhum., Mars, 1939, Nr. 3.

Contribution au traitement chirurgical de la sacralisation douloureuse de la cinquième lombaire. J. Gosset, Rev. du Rhum., Mars, 1939, Nr. 3.

Les coxo-femoroplasties dans le traitement fonctionnel du morbus coxæ senile. R. Massart, Rev. du Rhum., Mars, 1939, Nr. 3.

Biotropisme bismutique indirect de Milian à forme de rhumatisme. articulaire aigu, généralisé, fébrile. Petges et Dereço, Paris Méd., 4 Mars, 1939, Nr. 9.

Les infiltrations novocaïniques péri-articulaires dans le traitement de la goutte. Jung, Le Progr. Méd., 4 Mars, 1939, Nr. 9.

Tuberculococcoïdes. Erythème noueux, splénopneumonies, néphrites, hémorragiques ictères, rhumatismes. K. Lewkowicz, La Presse Méd., 15 Avril, 1939, Nr. 30.

Qu'est-ce que le psoriasis arthropatique? M. F. Françon, Annales de Méd. Phys. et de Rhum., 1939, Fasc. 4.

La névralgie sciatique par radiculo-arachnoïdite lombosacrée. S. de Sèze, Acta Baln. Pol., 1939.

Sciatique rebelle par hernie postérieure du ménisque intervertebral. P. Glorieux, Christophe F. Françon, Acta Baln. Pol., 1939.

Les réactions du liquide cephalo-rachidien au cours des polyarthrites chroniques. J. Graber-Duvernay et Fr. Gerbay, Acta Med. Scand., 1939, Fasc. I.-II., vol. C.

Rhumatisme infectieux avec adénopathie et grosse rate. L. Langeron, J. Camelot et A. Baude, J. des Sc. Méd. de Lille, 12 Mars, 1939, Nr. 11.

Le psoriasis arthropathique. F. Françon, Rev. Belge Sc. Méd., Mars, 1939.

Le rhumatisme et ses atteintes rénales. Albeaux-Fernet, Concours Méd., 23 Avril, 1939, Nr. 17.

Quelques interventions chirurgicales utiles dans le traitement des arthrites déformantes de la hanche. Massart, Concours Méd., 23 Avril, 1939, Nr. 17. 
Rhumatisme chronique et amylose. M. Villaret, L. J. Besançon, J. Delarue, P. Bardin and A. Rubens-Duval, Rev. du Rhum., Mai, 1939, Nr. 5.

Injections régionales de sulfamides dans le traitement des affections rhumatismales. F. Coste, M. Gaucher and M. Morin, Rev. $d u$ Rhum., Mai, 1939, Nr. 5.

Spondylose ankylosante et mal de Pott. R. J. Weissenbach, L. Perlès and P. Témine, Rev. du Rhum., Mai, 1939, Nr. 5.

Les processus desydrogénatifs du cartilage articulaire après la section des tendons musculaires qui s'attachent à l'articulation. A. Masturzo, Rev. du Rhum., Mai, 1939, Nr. 5.

La goutte climatérique. G. Maranon, Rev. $d u$ Rhum., Mai, 1939, Nr. 5.

Un cas d'ostéose thyroï dienne. F. Coste, M. Gaucher and G. Guyot, Rev. du Rhum., Mai, 1939, Nr. 5.

Les injections locales intra-articulaires dans le traitement des coxarthries. M. Morin, Rev. du Rhum., Mai, 1939.

La téléröntgenthérapie totale dans le traitement des affections rhumatismales. P. Lehmann, Rev. du Rhum., Mai, 1939.

Origine centrale possible d'un syndrome algique du type périarthrite de l'épaule. J. Morlaas, Rev. du Rhum., Mai, 1939.

Appareils de contention en matière cellulosique pour la prévention des déformations articulaires chez les rhumatisants. J. Forestier and A. Certonciny, Rev. du Rhum., Mai, 1939.

Traitement local des arthrites avec épanchement par les injections intra-articulaires de sulfamides. F. Layani, Rev. du Rhum., Mai, 1939.

Algies et arthralgies herpétiques. Jausion, Girard and Kouchner, Rev. du Rhum., Mai, 1939.

Note sur le traitement de l'acromélalgie de la ménopause et du rhumatisme d'Heberden. F. Coste and A. Thaon, Rev. du Rhum., Mai, 1939.

Comment prévenir les déformations rhumatismales. I. Gunzburg, Ann. de Méd. Phys. et de Rhum., 1939, fasc. vi.

Les sels minéraux de l'os. Le rôle des éléments minéraux en physiologie et en pathologie osseuse. M. Villaret and L. Justin-Besançon, Rev. du Rhum., Juin, 1939, Nr. 6.

Le rhumatisme xyphöïdien. A. Françon, Rev. du Rhum., Juillet, $1939, \mathrm{Nr} .7$.

Le traitement de la maladie de Still par le lacto-sérum en injections intramusculaires. L. Maldague, Ann. de Méd. Phys. de PhysioBiol. et de Rhumatisme, XXXIIe Année, 1939, fasc. viii.

La clef du diagnostic précose de la spondylarthrite est dans la radiographie des articulations sacro-iliaques. J. Forestier and J. Metzger, La Presse Méd., 16 Août, 1939, Nr. 6. 
Quelques indications pronostiques dans la sciatique cryptogène. F. Françon, La Presse Thermale et Climatique, 1-15 Juillet, 1939.

L'aspect clinique des arthrites chroniques de la hanche d'origine congenitale. J. Graber-Duvernay, Acta Med. Scand., 1938, vol. xciv., fasc. iv.-vi.

Traitment des péri-arthrites scapulo-humérales. Charry, J. Pract., 8 Aug., 1939, an. 53.

$\mathrm{Y}$-a-t-il des formes de rhumatisme articulaire et périarticulaire d'un nature réellement allergique? G. Kahlmeter, Am. Med. Scand., 1939 , vol. cii., fasc. iv.-v.

Recherches sur le venin d'abeilles. L. Binet and M. Burstein, La Presse Med., 1939, Nr. 81-82.

Le syndrome biologique du rhumatisme chronique progressif tuberculeux. R. J. Weissenbach, F. Françon, Perles and Matineau, $J$. Méd. de Lille, Juin, 1932.

\section{ENGLISH}

Pathological and Physiological Considerations of Arthritis. Th. H. Vinke, Physiother. Review, vol. xix., No. 3.

Chronic Arthritis in Wild Animals. H. Fox, Am. Philosoph. Soc., 1939, p. 76.

Value of Sulphur and Iodine in Treatment of Chronic Arthritis. E. Fletcher, J. Roy. Inst. Publ. Health, February, 1939.

Gold Therapy in Proliferative (esp. Atrophic) Arthritis. J. A. Key, H. Rosenfeld and O. E. Tjoflat, J. Bone and Joint. Surg., April, 1939.

Menopause and Painful Stiffening of the Shoulder. W. W. Voight, Illinois Med. J., April, 1939.

The Relief of Arthritic Symptoms following Urticaria. W. B. Rawls, J. Am. Med. Ass., June 17, 1939, No. 2.

The Atiology of Polyarthritis in the Rat. G. M. Findlay, R. D. Mackenzie, F. O. McCallum and E. Klieneberger, Lancet, July 1, 1939.

Low Back and Sciatic Pain from the Standpoint of the Neuro-Surgeon. R. G. Spurling and F. K. Bradford, Kentucky Med.J., May, 1939.

Pathogenic Pleuropneumonia-like Micro-organisms from Acute Rheumatic Exudates and Tissues. H. F. Swift and Th. McPherson Brown, Science, March 24, 1939, vol. lxxxix.

Non-operative Procedures for the Relief of Lumbo-Sciatica. W. M. Steel, Am. J. Surg., April, 1939.

Physical Treatment and the Rheumatic Knee. J. Mennell, British J. Rheumatism, April, 1939.

Osteosclerosis in Tuberculous Spondylitis. A Scheel, Nordisk Med., June 17, 1939, vol. ii. 
Chronic Recurring Sciatica: Diagnosis and Treatment of Protrusions of Ruptured Intervertebral Discs. A. W. Adson, Arch. Phys. Ther., June, 1939, vol. xx., pp. 325-330.

Further Studies on the Treatment of Chorea and Rheumatic Infection by Fever Induction. E. L. Bauer, Am. J. Med. Sciences, August, 1939, No. 2.

Local Tissue Anoxia and its Treatment (with Special Reference to Rheumatic Myocarditis). E. P. Poulton, Lancet, August 5, 1939 , p. 305.

Fasciotomy for Chronic Sciatica and Backache. J. A. Nutter, Can. Med. Ass. J.; June, 1939, vol. xl.

The Pathology of Osteoarthritis. D. H. Collins, Brit. J. Rheumatism, April, 1939.

Environmental Factors in Rheumatoid Arthritis. S. Cobb, W. Bauer and I. Whiting, J. Am. Med. Ass., August 19, 1939.

Local Injections and Regional Analgesia with Procaine Solutions for Intractable Pain in Chronic Arthritis and Related Conditions. O. Steinbrocker, Annals of Intern. Med., June, 1939, No. 12.

A Case of Erythema, Gout and Subleukæmic Myelosis. G. H. Reifenstein. Am. J. Med. Sciences, February, 1939, vol. cxcvii., No. 2.

Osteomalacia of the Spinal Column from Deficient Diet or from Disease of the Digestive Tract-I., II., III. E. Meulengracht, Acta Med. Scand., 1939, vol. ci., fasc. ii.-iii.

The Clinical Importance of Infection of the Respiratory Tract in Rheumatic Fever. T. D. Jones and J. R. Mote, J. Am. Med. Ass., September 2, 1939, vol. cxiii., No. 10.

Caloric and Vitamin Values in the Diet of the Arthritic Patient. K. K. Sherwood and M. E. Thomson, J. Am. Dietetic Ass., January, 1939.

Acute Rheumatic Carditis. W. T. Ritchie, Lancet, September 9, 1939.

Colon Disease and its Therapy in Relation to Chronic Arthritis. E. C. Fishbaugh, Arch. Phys. Ther., July, 1939.

Treatment of Arthritis with Acetyl Beta-Methylcholine Chloride. S. L. Osborne, D. Boyd and D. E. Markson, Arch. Phys. Ther., July, 1939.

Surgical Treatment of Chronic Constrictive Pericarditis. G. J. Heuer and H. J. Stewart, Surgery, Gyn. and Obst., June, 1939.

The Delayed Appearance of Heart Disease after Rheumatic Fever. T. D. Jones and E. F. Bland, J. Am. Med. Ass., October 7, 1939, No. 15.

Subacute Bacterial Endocarditis due to Streptococcus viridans, with Special Reference to Prognosis. J. A. Capps, Annals Intern. Med., August, 1939.

Short Wave Diathermy. J. S. Coulter, Med. Clin. N. America, January, 1939. 
Heart Sounds in Normal Children. M. H. McKee, Am. Heart J., July, 1938, No. 1.

The Problem of Rheumatism. J. G. Finder, Illinois Med. J., April, 1938.

Follow-up Report of Ninety-nine Children who received Fever Therapy for Chorea. L. P. Sutton and K. G. Dodge, J. Pediatrics, April, 1938, No. 4.

The Prognosis in "Potential Rheumatic Heart Disease" and " Rheumatic Mitral Insufficiency." J. A. Boone and S. A. Levine, Am. J. Med. Sciences, June, 1938, vol. cxcv., No. 6.

Cytologic Studies on Rheumatic Fever. C. McEwen, Arch. Path., March, 1938, vol. xxv.

A Simplified Method of Correcting the Sedimentation Rate for the Effect of Cell Volume. A. Hambleton and R. A. Christianson, J. Lab. and Clin. Med., May, 1938, vol. xxiii., No. 8.

Immunisation against Rheumatic Fever with Hæmolytic Streptococcus Filtrate. V. P. Wasson, Am. Heart J., March, 1938, vol. xv., No. 3.

Infection Experiments with Virus-like Bodies from Rheumatism. G. H. Eagles, P. R. Evans, J. D. Keith and A. G. Timbrell Fisher, J. Path. and Bact., 1938, No. 3.

The Tonsils and Sinuses in Rheumatoid Arthritis. R. L. McCollom, Laryngoscope, May, 1938.

Nasal Accessory Sinuses as Foci of Infection in Arthritis. H. L. Williams and C. H. Slocumb, Arch. Otolaryngology, May, 1939.

Sensitivity of Rheumatic Subjects to Streptococcal Products. C. A. Green, J. Path. and Bact., 1938, No. 2.

Treatment of Rheumatoid Arthritis with a New Gold Salt. S. J. Hartfall, H. G. Garland, W. Goldie, Lancet, December 17, 1938, p. 1410.

The Effects of Physical Treatment on the Arneth Count and Sedimentation Rate in Rheumatic Conditions. H. J. Gibson, Proc. Roy. Soc. Med., February, 1938, vol. xxxi.

The Treatment of Affections of the Joints with Progestine. J. F. Touw and R. K. W. Kuipers, Acta Med. Scand., 1938, fasc. v.-vi.

Some Aspects of Recent Work on the Bacteriology of Rheumatism. H. J. Gibson, Brit. Med. J., October 22, 1938, p. 827.

Ancient Arthritis. E. B. Chamberlain, Radiology, June, 1938, vol. xxx., No. 6.

Arthritis Deformans from the Viewpoint of an Orthopædist. N. Little, Med. J. Austr., October 22, 1938.

A Preliminary Report of the Prophylactic Use of Sulphanilamide in Patients Susceptible to Rheumatic Fever. C. B. Thomas and R. France, Bull. Johns Hopkins Hosp., January, 1939, vol. lxiv., No. 1 . 
Osteoarthritis. E. Fletcher, Brit. J. Rheumatism, October, 1939.

The Relationship of Sydenham's Chorea to Other Rheumatic Manifestations. L. Porter Sutton and K. G. Dodge, Am. J. Med. Sciences, May, 1938.

Gold Therapy in Tuberculosis and Arthritis. K. Secher, Lancet, April 30, 1938.

Public Health Aspect of Heart Disease in Childhood. B. Schlesinger, Lancet, March 12, 1938.

Serological Examination of Hæmolytic Streptococci from Acute Rheumatic and Control Grcups. C. A. Green, Brit. Med. J. May 28, 1938.

The Action of Sulphanilamide in Rheumatic Fever. H. F. Swift, J. K. Moen and G. K. Hirst, J. Am. Med. Ass., February 5, 1938.

Fever Therapy in Gonococcal Infections, with Especial Reference to Gonococcal Arthritis. T. G. Schnabel and F. Fetter, Am. J. Syph., Gon. and Ven. Dis., January, 1938, vol. xxii., No. 1.

Metabolism of Vitamin $\mathrm{C}$ in Rheumatoid Arthritis. J. F. Rinehart, L. D. Greenberg, F. Baker, S. R. Mettier, F. Bruckman and F. Choy, Arch. Intern. Med., April, 1938.

Pathology of Chronic Arthritis of Children (Still's Disease). R. B. Portis, Am. J. Dis. Children, May, 1938.

Artificial Fever Therapy of Gonorrhœal Arthritis. H. W. Kendell, W. W. Webb and W. M. Simpson, Am.J.Surgery, September, 1935, No. 3.

Metabolism of Vitamin C in Rheumatic Fever. J. F. Rinehart, L. D. Greenberg, M. Olney and F. Choy, Arch. Intern. Med., April, 1938.

The Relationship of the Intervertebral Disc to Back Strain and Peripheral Pain (Sciatic). J. S. Barr, Surgery, July, 1938, No. 1. Thyroid Activity in Chronic Arthritis. W. B. Rawls, A. A. Ressa, B. Gruskin and A. S. Gordon, Annals Intern. Med., February, 1938. Arthrodesis of the Osteoarthritic Hip. R. Watson-Jones, J. Am. Med. Ass., January 22, 1938.

Phosphatase Activity in Chronic Arthritis. C. Leroy Steinberg and L. C. Suter, Arch. Intern. Med., September, 1939, vol. lxiv., No. 3.

Bacteriology of Rheumatic Fever. W. R. F. Collis, Lancet, October 14, 1939, No. 6059.

Considerations Bearing on the Treatment of Arthritis. R. Pemberton, Am. J. Med. Sciences, November, 1939.

The Treatment of Arthritis with Massive Dosage Vitamin D. R. T. Fairley, J. Am. Inst. of Homeopathy, July, 1938.

Massive Doses of Vitamin D in Chronic Arthritis: its Effect in Calcium Metabolism. C. LeRoy Steinberg, J. Lab. and Clin. Med., October, 1938.

The Treatment of Gonorrhœal and Rheumatoid Arthritis with Sulphanilamide. H. C. Coggeshall, Trans. Ass. Am. Phys., 1938. 
Chronic Recurring Sciatic Pain due to Protruded Intervertebral Discs. J. G. Love, A. W. Adson and W. McK. Craig, Journal-Lancet, November, 1938.

Muscular Rheumatism and Spina Bifida Occulta. R. J. Dittrich, Am. J. Surg., November, 1938.

The Subcutaneous Nodule of Rheumatism. P. G. Gollerkeri, Ind. Med. Gaz., April, 1938.

\section{Other Languages}

Zakladowo-zdrojowiskowe leczenie gośćcowijch schorzeń narzadu ruchu w Ubezpleczeniu Spolecznym. E. Bokser, Acta Baln. Pol., 1939.

Contatti biologici e clinici fra reumatismo e tubercolosi. E. Greppi, La Settimana Medica, Nr. 1 en 2, 5 en 12 Gennais.

Lumbago. L. Smit, Gen. Ts. der Rijksverz. bank., Mei, 1939, Nr. 5.

Nogle uspecifike lidelserL. Lumbo-sacralregionnen og deres behandling. C. D. Bartels, Ugeskrift for Laeger, 1939, Nr. 1.

Estudio radiólogico del reumatismo cronico. A. O. Raffo, P. A. Maissa et V. H. Richeri, Rev. Arg. de Reum., May, 1939, No. 24.

Estudios sobre las afecciones reumaticas en la nosologia metodica de Sauvages. A. Ruiz Moreno, Bol. del Centro Antirreum., 1939, Nr. 1.

Reaccion de Weltmann y su valor en el reumatismo. A. Ruiz Moreno and A. M. Fassi, Bol. Centro Antirreum., 1939, Nr. 1.

Epifisitis vertebral. Cifosis dorsal juvenil de los adolescentes. B. A. Moreno, Bol. Centro Antirreum., 1939, Nr. 1.

L'infezione reumatica come causa d'invalidita. L. Condorelli, Difesa Soc. Maggio, 1939, Nr. 5.

Polyarthritis rheumatica acuta (rumatiekkoors) by die kind. C. F. van der Merwe, Suid Afr. Tydskr. v. Gen., 24 Junie, 1939.

Mediastinisis reumatica. J. C. Bertrand and E. Kirchmayer, Rev. Argent. de Reum., Junio, 1939, Nr. 25.

Röntgenbehandeling van spondylosis rhizomelica. P. B. V. Quaratero, Ned. T. v. Gen., 8 Juli, 1939, Nr. 27.

Considerationes sobre algunos problemas etiopatogénicos de las artritis reumáticas. A. Mester, Bol. del. Centro Antirreum., Oct., Nov., Dic., 1938.

Estudio experimental del reumatismo. B. A. Moreno, Bol. del. Inst. de clin. Quirurgica, Julio-Agosto, 1939, No. 127.

Spondylosis rhizomelica met röntgenstralen behandeld. P. B. V. Quartero, Ned. Ts. v. Gen., 16 Dec., 1939. 